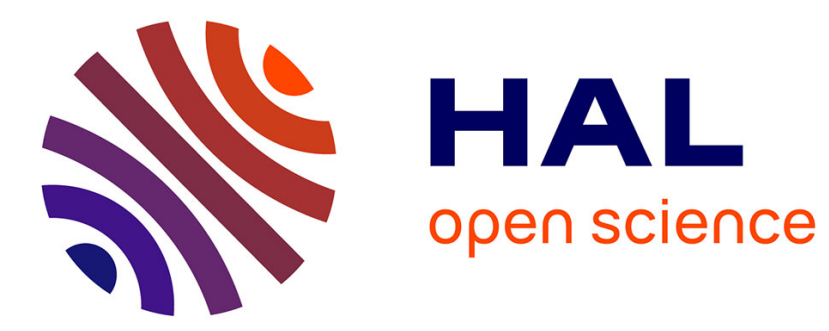

\title{
Grazing affects shoot growth, nutrient and water status of Quercus ilex L. in Mediterranean open woodlands
}

Alma M. García-Moreno, María D. Carbonero-Muñoz, María Serrano-Moral, Pilar Fernández-Rebollo

\section{- To cite this version:}

Alma M. García-Moreno, María D. Carbonero-Muñoz, María Serrano-Moral, Pilar Fernández-Rebollo. Grazing affects shoot growth, nutrient and water status of Quercus ilex L. in Mediterranean open woodlands. Annals of Forest Science, 2014, 71 (8), pp.917-926. 10.1007/s13595-014-0397-x . hal01102966

\section{HAL Id: hal-01102966 https://hal.science/hal-01102966}

Submitted on 13 Jan 2015

HAL is a multi-disciplinary open access archive for the deposit and dissemination of scientific research documents, whether they are published or not. The documents may come from teaching and research institutions in France or abroad, or from public or private research centers.
L'archive ouverte pluridisciplinaire HAL, est destinée au dépôt et à la diffusion de documents scientifiques de niveau recherche, publiés ou non, émanant des établissements d'enseignement et de recherche français ou étrangers, des laboratoires publics ou privés. 


\title{
Grazing affects shoot growth, nutrient and water status of Quercus ilex L. in Mediterranean open woodlands
}

\author{
Alma M. García-Moreno • María D. Carbonero-Muñoz • \\ María Serrano-Moral • Pilar Fernández-Rebollo
}

Received: 2 April 2014 / Accepted: 9 June 2014 / Published online: 27 June 2014

(C) INRA and Springer-Verlag France 2014

\begin{abstract}
- Context Mediterranean open woodlands (dehesa) have faced a dual process of intensification and abandonment of grazing which has resulted in alteration of the understory vegetation.

- Aims We analysed the effects of land use changes on the physiological status of holm oak in different open woodlands (dehesa) in southern Iberian Peninsula.

- Methods In an area of extensive grazing, we selected six paired plots (one grazed, one abandoned) and grouped them by habitat types according to understory composition (nearly all monospecific Cistus ladanifer L. shrub or mixed shrub). Six plots of moderate and heavy grazing intensity were chosen within a settled area of livestock use. Shoot growth, macronutrient concentrations and water content were assessed in samples of holm oak leaves.
\end{abstract}

\section{Handling Editor: Gilbert Aussenac}

Contribution of the co-authors P. Fernández-Rebollo conceived the idea. A. García-Moreno, M.D. Carbonero-Muñoz and M. SerranoMoral performed the field samplings and laboratory measurements. A. García-Moreno and P. Fernández-Rebollo analysed the data and wrote the paper.

Executive summary The abandonment of grazing in Mediterranean open woodland enhances or makes worse the habitat for trees, depending on shrub species involved in encroachment process. In areas with ancient livestock use, tree growth and leaf $\mathrm{N}$ concentration increase with grazing intensity.

A. M. García-Moreno • M. D. Carbonero-Muñoz

P. Fernández-Rebollo $(\bowtie)$

Department of Forestry, ETSIAM, University of Cordoba,

Campus de Rabanales, Leonardo Da Vinci, Apdo. 3048,

14071 Córdoba, Spain

e-mail: ir1ferep@uco.es

M. Serrano-Moral

Department of Agronomy, ETSIAM, University of Cordoba, Campus de Rabanales, Leonardo Da Vinci, Apdo. 3048,

14071 Córdoba, Spain
- Results Abandonment of grazing affected some nutrient concentrations and water content of holm oak leaves, but the effects were different according to habitat type. C. ladanifer shrub reduced $\mathrm{N}$ and $\mathrm{P}$ concentrations and water content while mixed shrub increased $\mathrm{P}$ concentration and water content. High grazing intensity improved shoot growth and leaf $\mathrm{N}$ and $\mathrm{Mg}$ concentrations.

- Conclusion Extensive grazing could be a useful management tool to enhance growth, nutritional and water status of holm oak in a habitat with limited resources such as Mediterranean open woodlands (dehesa).

Keywords Holm oak - Leaf nutrient concentrations - Water content $\cdot$ Shoot length $\cdot$ Dehesa

\section{Introduction}

Quercus trees are widespread in many types of woodland in the Northern Hemisphere. In the Mediterranean basin, the sclerophyllous evergreen holm oak (Quercus ilex L.) is a common species which is found over an area extending from Portugal to Syria and from Morocco and Algeria to France. The holm oak is widespread in the Iberian Peninsula and is the dominant species in open woodlands (known as dehesa in Spain and montado in Portugal).

Like other savanna ecosystems in the world (McPherson 1997), the Mediterranean open woodland in the Iberian Peninsula is the result of human intervention in denser natural woodlands, by eliminating trees and shrubs to facilitate grazing, acorn production and occasional cereal and legume crops. Hence, the vegetation in this ecosystem consists of two distinct layers: a tree layer and a pasture or crop understory. The main land use is for livestock (sheep, cattle and Iberian pigs), which are mainly fed on the pasture and crops. These woodlands also provide forest products, such as firewood and cork 
(where Quercus suber L. is present), as well as game for hunting (Moreno and Pulido 2009). In order to prevent shrub encroachment, Mediterranean open woodland requires constant human intervention. Although periodic ploughing and cropping are common practices to avoid shrub encroachment, livestock are the main tool used for preventing shrubs from colonizing the pasture.

Over the last few decades, Mediterranean open woodlands have faced a dual process of intensification and abandonment, due to the socioeconomic changes occurring in most European countries. For example, cattle have gradually replaced sheep as the main livestock in open woodlands in the Iberian Peninsula, mainly as a consequence of the higher labour demand required for sheep farming together with the drastic fall in the price of wool. Nowadays, this change is reflected in the livestock census, where sheep flocks have fallen by over $20 \%$ in the last 10 years, while cattle herds have increased (Gaspar et al. 2007). Furthermore, as a result of reforms in the European Common Agricultural Policy, a noticeable increase in the stocking rate has taken place in many areas. On the other hand, open woodlands located in marginal areas have been abandoned, and these areas are now grazed by wild animals instead of livestock. This dual process of intensification and abandonment of grazing, which can even coexist on a local scale, has resulted in a change in the structure, composition and production of the vegetation.

Trees, the key element of the Mediterranean open woodland, have been affected by these changes in land use, in addition to the problems they face from climate change. Several studies have analysed the effect of land use changes on different areas of oak open woodland, focusing mainly on vegetation structure (Ramírez and Díaz 2008; Strandberg et al. 2005), floristic composition of pasture (Peco et al. 2006; Tárrega et al. 2009), tree regeneration (Pulido et al. 2010) and soil quality (GómezRey et al. 2013; Seddaiu et al. 2013; Strandberg et al. 2005). However, less information is available about the effects of land use changes on the status of mature holm oaks.

The abandonment of grazing encourages the invasion of shrubs, which eventually replace the pasture. In areas where marginal shrub patches are dominated by Cistus species, a decrease in grazing leads to a rapid encroachment of shrubs (Ramírez and Díaz 2008; Tárrega et al. 2009), thus reducing the diversity of vegetation (Peco et al. 2006). Nevertheless, this encroachment process may occur slowly if more shrub species are present. The introduction of a new layer of woody vegetation in open woodlands can alter the physiological status of mature holm oak and boost its chances of its survival. Moreover, when widespread encroachment occurs, the persistence of adult trees in these ecosystems can be threatened, in spite of the beneficial effects of shrubs in helping seedling and sapling survival through nursing effects (Pulido et al. 2010). Several authors have described how shrub-tree interactions can reduce the opportunities for existing trees (Silva and Rego
2003; Cubera and Moreno 2007), due to competition for soil nutrients and water in semiarid environments. Experimental evidence supports the assumption that water limitations affect tree nutrient levels (Sardans et al. 2008). Other studies emphasize the ability of shrub species to alter soil environment directly through the production of toxin or allelopathic compounds (Chaves and Escudero 1997; Dias et al. 2010) or by indirectly affecting microclimatic conditions (Pulido et al. 2010). Nevertheless, there is a general consensus over the fact that the nature and degree of shrub-tree interactions depend largely on the species (Rolo et al. 2012).

The increase in grazing intensity and the intensification of livestock systems in open woodlands prevent shrub invasion and may improve soil fertility and the production and quality of pasture, as occurs in other pastoral systems (Augustine and Mcnaughton 2006). With better soils and a separate rootingniche for both functional groups - pasture and tree (Moreno and Pulido 2009) - holm oaks may also improve their nutritional, physiological and productive status. Nevertheless, soil degradation due to overgrazing has been widely reported in temperate and semiarid pastures (Greenwood and McKenzie 2001; Drewry et al. 2008), and this degradation may lead to decreased holm oak growth and production. Therefore, the status of the holm oak in this situation depends on the net result of multiple interactions which rely mainly on farming practices.

In order to clarify the effects of these land use changes on trees, we analysed the shoot growth, nutrient and water status of holm oak leaves in different areas of open woodland in the southern Iberian Peninsula. We chose two areas of open woodland: the first area, stretching across north-western Andalusia, is a good example of the process of abandonment, whereby patches of open woodland subject to low-intensity grazing over a long period of time are interspersed with areas which are rarely grazed and hence have a dense shrub understory. We expected shrub-tree interaction to be dependent on shrub type (Rolo et al. 2012), and so we selected two types of habitats according to the shrub composition: nearly monospecific Cistus ladanifer L. or mixed shrubland. The second area, a smaller area located in the north of Andalusia, represents intensified open woodland whose pasture understory has been continuously grazed by livestock at different intensities over a long period of time. Using this framework, we hypothesized that moderate grazing increases soil nutrient availability, which could enrich the nutrient status and tree growth, but that heavy grazing may have an adverse effect. We therefore posed the following specific questions: (i) what impact shrub encroachment, through the abandonment of grazing, has on leaf-level macronutrient concentrations and water content of holm oak and whether this tree response is mediated by shrub type and (ii) what the impact of grazing intensity is on shoot growth and leaf macronutrient concentrations of holm oak. 


\section{Materials and methods}

\subsection{Study area and experimental layout}

The study was conducted on different dehesa farms located in Andalusia (South-western Spain, $37^{\circ} 72^{\prime}-38^{\circ} 25^{\prime} \mathrm{N}, 04^{\circ} 18^{\prime}-$ $07^{\circ} 11^{\prime} \mathrm{W}$ ). The climate of the area is Mediterranean with hot, dry summers and mild, rainy winters. The soils are slightly thick, oligotrophic and acidic (IUSS Working Group 2006). Some features of the soils, climate and vegetation of the area studied are shown in Table 1. The vegetation of these farms is characterized by scattered adult trees at the top layer, where holm oak (Quercus ilex L.) is the dominant species. The understory consists of natural pasture of herbaceous annuals or shrubs.

Two samplings were carried out. For the first one, we evaluated the effect of the abandonment of grazing on water and nutrient concentrations of holm oak leaves. Six dehesa farms (A-F) located in the provinces of Cordoba, Huelva and Seville were selected. On each farm, two adjacent plots with similar soil, slope and tree coverage but with different land use were selected: grazed areas (native pasture+holm oak) and abandoned areas (shrub species+holm oak). Farms were grouped into two habitat types according to the shrub composition of the abandoned area: Cistus shrub, consisting of nearly all monospecific C. ladanifer $\mathrm{L}$. shrub, found on farms A, B and C; and mixed shrub, composed mainly of Quercus coccifera L. and Pistacia lentiscus L., with presence of Rosmarinus officinalis L. and Cistus spp. found on farms D, $\mathrm{E}$ and $\mathrm{F}$ (Table 1). In the second sampling, we evaluated the effect of grazing intensity on the nutrient status of the holm oak leaves and shoot growth. An area of open woodland (named G in Table 1) was selected in the district of Los Pedroches (northern Andalusia, Spain). This site covers an area of about $840 \mathrm{~km}^{2}$ with similar climatology. The soils are shallow and slightly acidic with a sandy texture (with abundant granite and quartz rocks). Twelve plots (paddocks) used for cattle, pig and sheep rearing were selected in this area: six with high intensity and six with moderate intensity of grazing. The allocation of grazing intensity tallied with the farm stocking rate data: around 1.2 livestock unit (LU) per ha in the first group and $0.4 \mathrm{LU}$ per ha in the second group.

\subsection{Sampling protocol}

In the first sampling, 10 holm oaks were selected in each plot. A sample of leaves was collected from each tree in July (six farms $\times$ two types of land use $\times 10$ trees $=120$ leaf samples). Each sample consisted of 30 fully expanded mature leaves, without impurities or symptoms of pathogens or defoliators. Several branches were cut from the south-facing side of the tree at the middle section of the crown. The leaves were collected from the middle section of the current season's shoot growth. The leaf samples were stored in plastic containers $(100 \mathrm{ml})$, sealed with Parafilm and placed in a portable cooler ready for processing in the laboratory.

In the second sampling, seven holm oaks were selected in each plot, and a sample of leaves was collected from each tree in October $(12$ plots $\times$ seven trees $=84$ leaf samples $)$, following the same methodology described above. The length of 10 current-year shoots was measured in each tree as an indicator of tree growth. In addition, one composite soil sample was collected per plot to a depth of $0-15 \mathrm{~cm}$ in open spaces (10 subsamples per sample). Soil penetration resistance (cone Index, hereafter $\mathrm{CI}$ ) was evaluated using a cone penetrometer with a fine tip (cone diameter $12.6 \mathrm{~mm}$, tip angle $30^{\circ}$ and rod diameter $9.5 \mathrm{~mm}$ ) following the recommendations established by standard ASAE S313.2 for soils with high mechanical impedance. Twenty CI measurements per plot were taken in the open spaces, to a depth of $5 \mathrm{~cm}$ at intervals of $0.5 \mathrm{~cm}$. The CI measurements were then averaged to produce a single mean value per plot.

\subsection{Analytical procedures}

Leaf samples collected in both samplings were air-dried at $65^{\circ} \mathrm{C}$ until the constant weight was reached, and then were ground in a stainless steel grinder to determine their total contents of $\mathrm{N}, \mathrm{P}, \mathrm{Ca}, \mathrm{Mg}$ and $\mathrm{K}$. $\mathrm{N}$ content was determined by the Kjeldahl method after the dry-ashing digestion method, $\mathrm{P}$ by the yellow colour method using vanadomolybdophosphoric acid, $\mathrm{Ca}$ and $\mathrm{Mg}$ by atomic absorption spectrometry and $\mathrm{K}$ by flame emission spectrometry. Leaf water content (hereafter, WC) was determined in the leaf samples collected in the first sampling according to the expression $\mathrm{WC}=((\mathrm{FW}-\mathrm{DW}) / \mathrm{DW}) \times 100$, where $\mathrm{FW}$ is the fresh weight and DW is the dry weight, obtained after air-drying at $65^{\circ} \mathrm{C}$ until the constant weight was reached. The soil samples were air-dried, sieved $(2 \mathrm{~mm})$ and analysed: soil texture percentage (clay, sand and silt), $\mathrm{pH}$, soil organic matter (SOM) (by Walkley and Black method), available P (by Olsen), organic $\mathrm{N}$ (by Kjeldahl), cation exchange capacity (CEC) (1.0 $\mathrm{M}$ ammonium acetate, $\mathrm{pH} 7.0$ ), and exchangeable base cations (1.0 M ammonium acetate extraction and flame emission spectrometry for $\mathrm{Na}$ and $\mathrm{K}$, atomic absorption spectrometry for $\mathrm{Ca}$ and $\mathrm{Mg})$. Percent base saturation (\%BS) was calculated by multiplying the sum of the extractable bases by 100 and dividing it by the CEC.

\subsection{Statistical analysis}

In the first sampling, the mean values of leaf nutrient concentrations $(\mathrm{N}, \mathrm{P}, \mathrm{K}, \mathrm{Ca}$ and $\mathrm{Mg}$ ) and $\mathrm{WC}$ were compared in each habitat type by a factorial ANOVA with land use and farm as fixed and random factors, respectively. In addition, a principal components analysis (PCA) was performed to extract the 


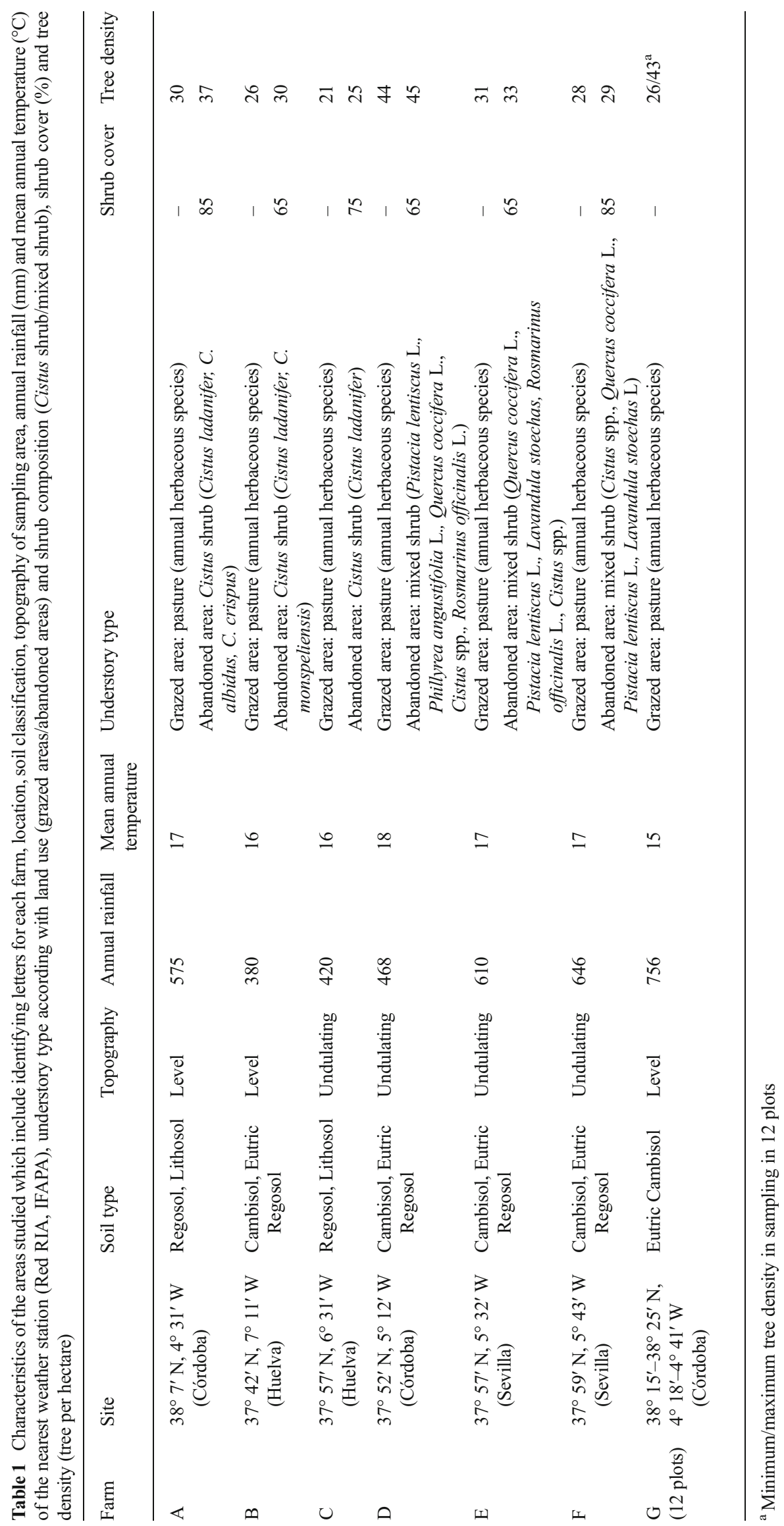


main variables involved in the dissimilarity between habitats and land uses. Average leaf concentrations of N, P, K, Ca and $\mathrm{Mg}$ and WC per plot were included in the PCA.

In the second sampling, the effects of grazing intensity and plot on leaf nutrient concentrations and shoot length were assessed through a nested ANOVA, in which the plot was a random factor nested in grazing intensity. Moreover, the effects of grazing intensity on soil properties were assessed by a one-way ANOVA. Normality was checked by the ShapiroWilk test and homoscedasticity by the Levene test. When these conditions were not fulfilled, the values were transformed logarithmically $[(\ln (x+1)]$. Fisher's test was applied for post hoc comparisons when ANOVA was significant $(p \leq 0.05)$. Finally, the relationships between nutrients in leaves and soil were analysed by Pearson's correlation coefficient. All statistical analyses were performed using the STATISTICA v 6.0 software.

\section{Results}

3.1 Effects of land use and types of shrub understory on leaf nutrient concentrations and water status

Significant differences were found in leaf $\mathrm{N}$ concentration and WC between land uses in Cistus shrub habitat (Table 2). Trees in abandoned areas showed lower leaf $\mathrm{N}$ concentration and $\mathrm{WC}$ than trees in grazed areas (Fig. 1). Foliar $\mathrm{K}, \mathrm{Ca}$ and $\mathrm{Mg}$ concentrations were not affected by land use. Foliar $\mathrm{P}$ concentration decreased in abandoned areas, although differences were only found on one farm, where the interaction between farm and land use factors was significant. As regards the mixed shrub habitat, significant differences were found in leaf
$\mathrm{P}$ concentration and WC between land uses, but unlike the former case, the lowest values were found in grazed areas. Foliar $\mathrm{K}, \mathrm{Ca}, \mathrm{Mg}$ and $\mathrm{N}$ concentrations were not affected by land use, and interactions between factors were not found.

The PCA extracted two principal components representing $69 \%$ of the variances in the nutrient and water status of the leaves. Variables with significant loadings on PC1 were WC $\left(R^{2}=0.80\right), \mathrm{Ca}\left(R^{2}=0.78\right)$ and $\mathrm{Mg}\left(R^{2}=-0.71\right)$, while $\mathrm{N}$ $\left(R^{2}=-0.78\right)$ had a negative loading on PC2 (Fig. 2). P and $\mathrm{K}$ leaf concentrations also contributed to the PC1 and PC2 definitions, although these were only marginally significant. The plot scores in PC1 (Fig. 2) showed that negative values were obtained for farms $\mathrm{A}, \mathrm{B}$ and $\mathrm{C}$, included in the Cistus shrub habitat, while positive values were obtained for farms D, E and F included in the mixed shrub habitat. Differences were observed in PC2 in plots of the Cistus shrub habitat according to land use, where abandoned plots were separated from grazed plots. However, plots in the mixed shrub habitat did not show any differences in land use.

3.2 Effect of grazing intensity on leaf nutrient concentrationst and shoot length

The analysis of the variances revealed that CEC, SOM content, available $\mathrm{P}$, organic $\mathrm{N}$, exchangeable base cations $\mathrm{K}^{+}$and $\mathrm{Ca}^{2+}$ and CI were significantly different according to grazing intensity (Table 3 ). Also, the $\mathrm{pH}$ showed a marginally significant difference. Soil texture and exchangeable base cations $\mathrm{Mg}^{2+}$ and $\mathrm{Na}^{+}$were similar for both groups.

Pearson's correlations between leaves and topsoil nutrients were not significant in any cases (data not shown). Grazing intensity had an effect on the concentrations of some leaf macronutrients (Fig. 3, Table 4). N

Table 2 Results from a factorial ANOVA testing the effect of land use (grazed areas/abandoned areas), as fixed factor, and farm, as random factor, on foliar nutrient concentrations and water content (WC) of holm oak in two habitat types (Cistus shrub/mixed shrub)

\begin{tabular}{|c|c|c|c|c|c|c|c|}
\hline & d.f. & Nitrogen & Phosphorus & Potassium & Calcium & Magnesium & WC \\
\hline \multicolumn{8}{|l|}{ Cistus shrub } \\
\hline Farm & 2 & 2.08 & 2.83 & 3.68 & $6.40 * *$ & $4.85^{*}$ & 2.13 \\
\hline Land use & 1 & $40.87 * *$ & $6.92 *$ & 0.02 & 0.25 & 3.19 & $6.57^{*}$ \\
\hline Farm $\times$ land use & 2 & 0.05 & $4.49 *$ & 1.22 & 5.72 & 2.70 & 1.17 \\
\hline \multicolumn{8}{|l|}{ Mixed shrub } \\
\hline Farm & 2 & 0.91 & $4.95^{*}$ & $6.00 * *$ & 2.11 & $19.06^{* *}$ & 2.67 \\
\hline Land use & 1 & 0.95 & $4.52 *$ & 0.16 & 1.32 & 0.02 & $10.08^{* *}$ \\
\hline Farm $\times$ land use & 2 & 0.91 & 1.39 & 2.41 & 0.75 & 0.27 & 2.69 \\
\hline
\end{tabular}

$F$ values are shown

$* p<0.05$, significant difference

$* * p<0.01$, significant difference 
Fig. 1 Mean values $( \pm$ SE) of nutrient concentrations and water comparing land use (grazed areas/ abandoned areas) in two habitat types (Cistus shrub/mixed shrub) content in leaves of holm oak
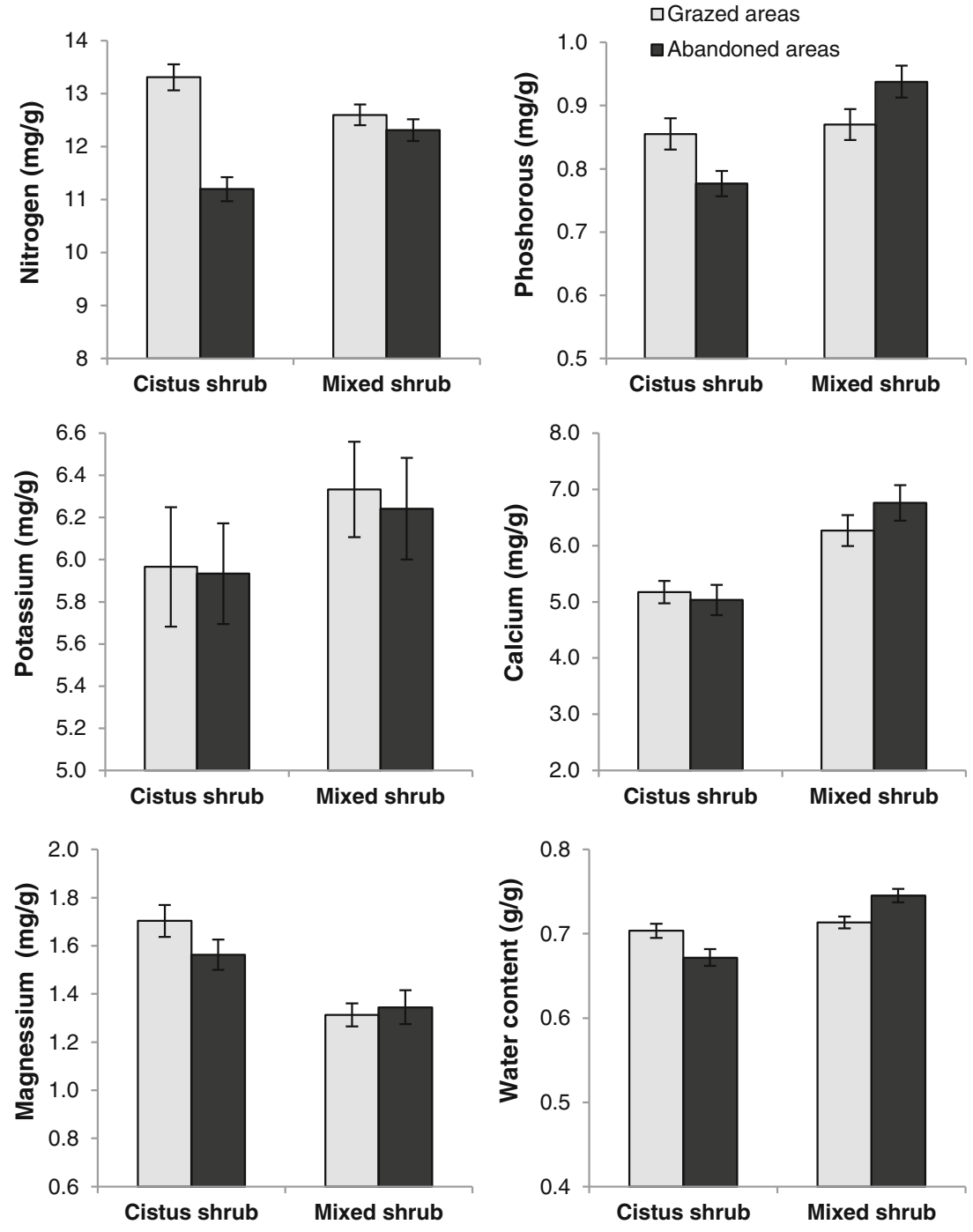

Fig. 2 Loading and score plots of principal components analysis performed with foliar nutrient concentrations $(\mathrm{N}, \mathrm{P}, \mathrm{K}, \mathrm{Ca}$ and $\mathrm{Mg}$ ) and foliar water content (WC) of holm oak in 12 plots within two habitat types (Cistus shrub/mixed shrub) and with different land use (grazed areas/ abandoned areas)

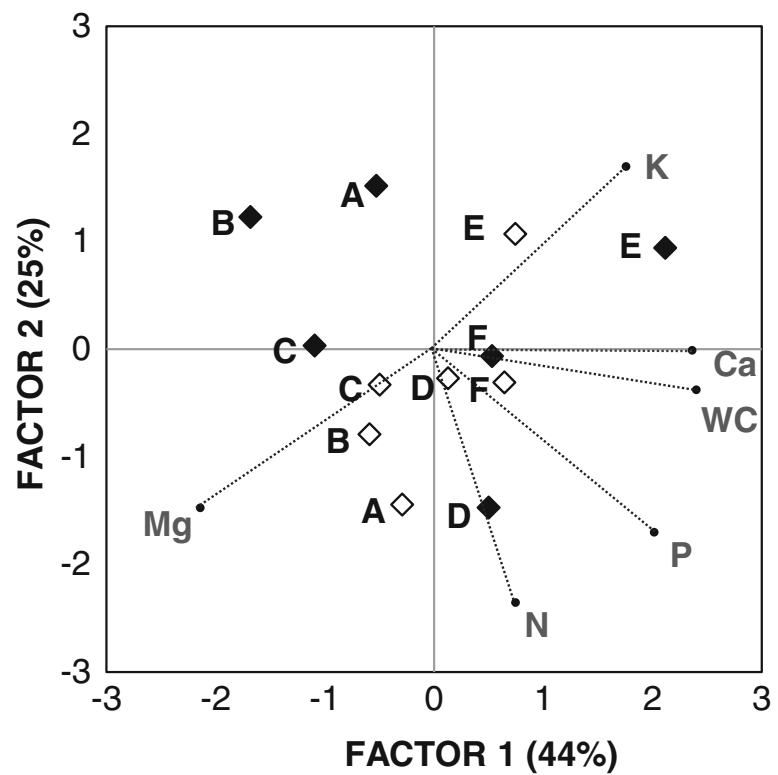

Cistus shrub (A, B, C) Mixed shrub (D, E, F)

- Factor loading (x3)

$\diamond$ Grazed areas

- Abandoned areas 
Table 3 Mean values $( \pm \mathrm{SE})$ of soil properties according to grazing intensity (moderate/high) and results of one way ANOVA testing the effect of grazing intensity on soil properties in open woodlands with a long history of livestock use

\begin{tabular}{|c|c|c|c|c|c|c|}
\hline \multirow[b]{3}{*}{ CI (MPa) } & \multicolumn{6}{|c|}{ Grazing intensity } \\
\hline & \multicolumn{2}{|c|}{ Moderate } & \multicolumn{2}{|l|}{ High } & \multirow{2}{*}{$\begin{array}{l}F \\
10.59\end{array}$} & \multirow{2}{*}{$\frac{p}{<0.01}$} \\
\hline & 2.15 & \pm 0.18 & 2.82 & \pm 0.10 & & \\
\hline$\%$ Clay & 5.4 & \pm 0.4 & 6.1 & \pm 0.4 & 1.51 & 0.24 \\
\hline$\%$ Sand & 80.1 & \pm 1.4 & 78.3 & \pm 1.1 & 1.05 & 0.32 \\
\hline$\%$ Silt & 14.4 & \pm 1.3 & 15.6 & \pm 1.2 & 0.44 & 0.52 \\
\hline $\mathrm{pH}$ & 5.50 & \pm 0.11 & 5.85 & \pm 0.13 & 4.10 & 0.07 \\
\hline $\mathrm{SOM}(\mathrm{g} / \mathrm{kg})$ & 19.26 & \pm 1.92 & 31.18 & \pm 3.53 & 8.71 & $<0.01$ \\
\hline Available P (mg/kg) & 6.9 & \pm 1.1 & 20.2 & \pm 4.16 & 11.08 & $<0.01$ \\
\hline CEC (meq/kg) & 74.9 & \pm 3.8 & 104.7 & \pm 5.3 & 20.59 & $<0.01$ \\
\hline $\mathrm{K}^{+}(\mathrm{meq} / \mathrm{kg})$ & 2.9 & \pm 0.2 & 5.2 & \pm 0.6 & 10.48 & $<0.01$ \\
\hline $\mathrm{Ca}^{2+}(\mathrm{meq} / \mathrm{kg})$ & 31.7 & \pm 2.5 & 45.2 & \pm 3.5 & 9.83 & $<0.01$ \\
\hline $\mathrm{Mg}^{2+}$ (meq/kg) & 23.0 & \pm 2.6 & 20.3 & \pm 2.7 & 0.51 & 0.48 \\
\hline $\mathrm{Na}^{+}(\mathrm{meq} / \mathrm{kg})$ & 3.1 & \pm 0.3 & 3.5 & \pm 0.3 & 1.39 & 0.26 \\
\hline Organic N (g/kg) & 0.75 & \pm 0.05 & 1.20 & \pm 0.18 & 5.76 & 0.04 \\
\hline$\% \mathrm{BS}$ & 81 & \pm 5.69 & 71 & \pm 2.55 & 2.79 & 0.12 \\
\hline
\end{tabular}

Exchangeable cations: $\mathrm{K}, \mathrm{Ca}, \mathrm{Mg}$ and $\mathrm{Na}$

$C I$ cone index, $S O M$ soil organic matter, $C E C$ cation exchange capacity, $B S$ base saturation percentage

and $\mathrm{Mg}$ concentrations in leaves were significantly higher in trees growing in heavily grazed plots. $\mathrm{Mg}$ concentrations showed significant differences between plots with similar grazing intensity, which were less significant than between the different groups of grazing intensity. However, $\mathrm{Ca}, \mathrm{K}$ and $\mathrm{P}$ concentrations were not affected by grazing intensity, but there were differences in foliar P concentrations between plots within the same grazing intensity. Shoot length was significantly lower in trees from plots with moderate grazing, in spite
Table 4 Results from a nested ANOVA design testing the effect of grazing intensity (moderate/high), as fixed factor, and plot, as random nested factor, on foliar nutrient concentrations and shoot length of holm oak in open woodlands with a long history of livestock use

\begin{tabular}{|c|c|c|c|c|}
\hline \multirow[t]{2}{*}{ Nutrients } & \multicolumn{2}{|c|}{ Grazing intensity } & \multicolumn{2}{|c|}{ Plots (grazing intensity) } \\
\hline & $F$ & $p$ & $F$ & $p$ \\
\hline $\mathrm{N}$ & 12.89 & $<0.01$ & 1.82 & 0.07 \\
\hline $\mathrm{P}$ & 1.28 & 0.26 & 2.64 & $<0.01$ \\
\hline $\mathrm{K}$ & 3.01 & 0.08 & 1.47 & 0.17 \\
\hline $\mathrm{Ca}$ & 0.13 & 0.71 & 1.41 & 0.19 \\
\hline $\mathrm{Mg}$ & 40.09 & $<0.01$ & 1.99 & 0.04 \\
\hline Shoot length & 31.88 & $<0.01$ & 3.03 & $<0.01$ \\
\hline
\end{tabular}

of the fact that shoot length showed significant differences between plots with a similar grazing intensity.

\section{Discussion}

The functioning of the holm oak in Mediterranean open woodlands is dictated by the environment in which the trees are established, where climate and soil are the main forces that determine its growth pattern. In our study, the first PCA axis performed on all the leaf nutrients and water content seems to reflect the environmental conditions of the farm, distinguishing trees that grow in different types of habitat. Farms with a mixed shrub habitat showed higher rainfall (average value $574 \mathrm{~mm}$ ) and more fertile soils (Cambisols and Eutric Regosols) than farms with a Cistus shrub habitat, which had less rainfall (average value $458 \mathrm{~mm}$ ) and more restrictive soils (Lithosols). Therefore, trees are expected to perform better in the first habitat. Better environmental
Fig. 3 Mean values $( \pm$ SE) of foliar nutrient concentrations and shoot length of holm oak according to grazing intensities (moderate/high) in open woodlands with a long history of livestock use

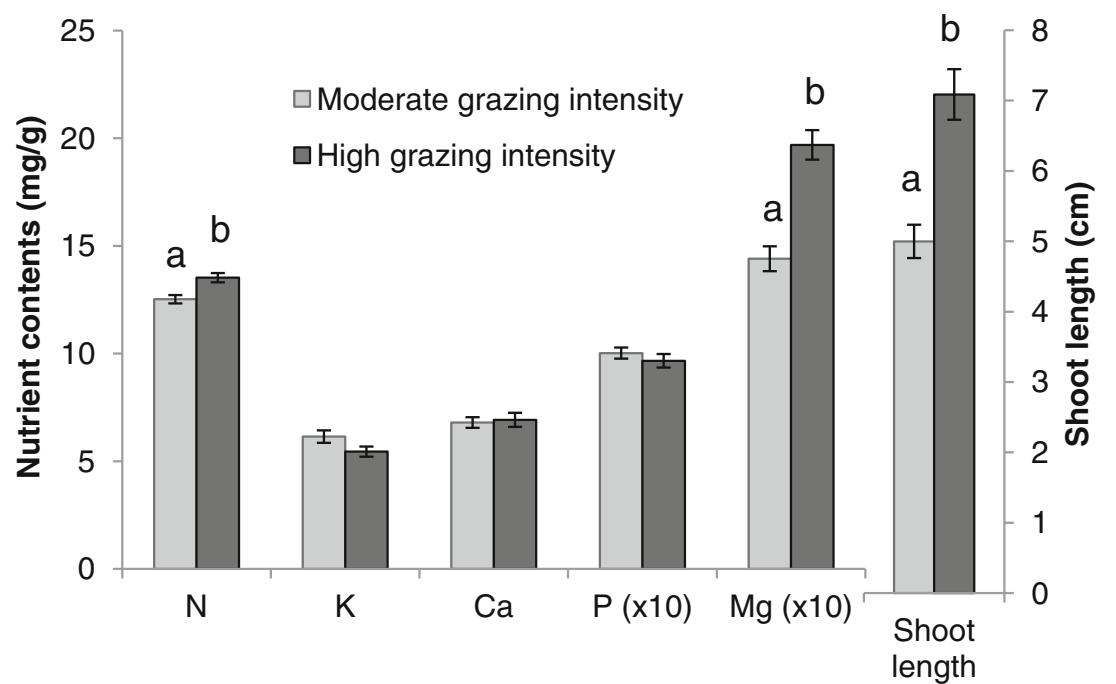

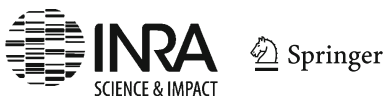


conditions were linked to leaf $\mathrm{Ca}$ concentration and water content. Because the movement of $\mathrm{Ca}$ in plants is mainly driven by transpiration flow and is seldom redistributed after its deposition in tissues, $\mathrm{Ca}$ concentration must consequently be high in tissues with a high transpiration rate and a long growth period (Yang and Jie 2005). However, more restrictive environments seem to be associated with $\mathrm{Mg}$ concentration at leaf level. According with this, in an experiment carried out in a holm oak forest, Sardans et al. (2008) reported a difference in $\mathrm{Mg}$ leaf concentration after a period of induced drought. Nevertheless, these authors argued that it was difficult to discern whether the increase in $\mathrm{Mg}$ concentration was a plant response to drought or a result of decreased soil fertility.

Nevertheless, within an environment, land use may affect the availability of nutrients for trees through the changes in the structure and composition of vegetation and in soil fertility. In this regard, the second PCA axis seems to discriminate trees according to land use, but only in the Cistus shrub habitat. The concentration of foliar $\mathrm{N}$ was the main nutrient which reflected the holm oak's response to the abandonment of grazing in this habitat. There are several possible explanations for this outcome. Firstly, C. ladanifer, in this case the dominant species in abandoned areas, has a strong ability to transform its surrounding environment through allelopathic compounds, which reduces the density and diversity of plant species in the communities where it grows (Chaves and Escudero 1997). Several studies have reported a negative effect of polyphenols included in allelopathic substances on net nitrification (Erickson et al. 2000) and $\mathrm{N}$ mobilization (Schimel et al. 1996), and this reduces $\mathrm{N}$ availability for vegetation. Hence, the effects of $C$. ladanifer on the dynamics of soil $\mathrm{N}$ could explain the lower leaf $\mathrm{N}$ concentration found in holm oaks in plots without grazing. In this regard, Dias et al. (2010) showed that the increase in soil N makes the encroachment of $C$. ladanifer more difficult. Secondly, grazing may accelerate the cycle of $\mathrm{N}$, increasing the size of the inorganic $\mathrm{N}$ pool available to plants at the onset of the growing season (Peco et al. 2006; Augustine and Mcnaughton 2006), which explains the results found in grazed areas on farms belonging to the Cistus shrub habitat. However, no differences were found in leaf $\mathrm{N}$ concentration owing to land use in a mixed shrub habitat, which suggests that grazing may have little effect on soil $\mathrm{N}$ availability in some sites or, alternatively, that mixed shrubs may have a positive effect on the soil $\mathrm{N}$ pool. As regards the effect of the grazer, Ritchie et al. (1998) found that herbivores may decrease the rate of $\mathrm{N}$ cycling, depending on the type of resources that limits plant growth. If plant growth is limited by $\mathrm{N}$ and dominant species have low N-tissues, herbivores may slow the cycle of this nutrient, while may accelerate it when the dominant species have tissues with high level of $\mathrm{N}$ that allows good efficiency in the use of other resources. Additionally, Augustine and Mcnaughton (2006) found that herbivores also decreased the rates of $\mathrm{N}$ mineralization, suggesting that the combined effects of grazers on inorganic $\mathrm{N}$ and $\mathrm{N}$ mineralization rates may result in a net increase or decrease in $\mathrm{N}$ availability. A positive effect of shrubs on soil N was found by Moreno and Obrador (2007). They showed that the presence of shrubs in holm oak open woodlands due to low-level grazing increases the content of organic matter, total $\mathrm{N}$ and exchangeable cations in the soil due to the long-term integration of fallen leaves into the soil. In Quercus pyrenaica open woodlands, the level of soil $\mathrm{N}$ in a grazing site was similar to abandoned sites (Tárrega et al. 2009). Therefore, the effects of grazing/shrub encroachment on soil $\mathrm{N}$ dynamics seem to be complex and must be understood in the context of each habitat.

In both habitats, land use did not have any effect on the $\mathrm{K}$ concentration in leaves. The high mobility of this cation in plants at all levels (between cells and tissues and also in the distribution through the xylem and phloem) and its role in osmoregulation processes (Benlloch-González et al. 2008) could explain these results. According to Milla et al. (2005), an important remobilization of $\mathrm{K}$ from older to newer branches occurs in holm oaks in mid-summer as a response to water stress and the need for a better osmotic adjustment which could allow these new branches to survive.

With regard to $\mathrm{P}$ leaf concentration compared with trees in grazed areas, our results demonstrate a degree of competition among holm oak and Cistus spp. shrubs and a mutualism between holm oak and mixed shrubs. These results are consistent with other studies which found that $\mathrm{P}$ absorption by holm oaks can be encouraged by the presence of high shrub diversity (Moreno and Obrador 2007) or discouraged by monospecific shrubs (Rolo et al. 2012). Arbuscular mycorrhizal fungi appear to be directly linked to the increased capacity of trees to exploit the soil and particularly to use the less prevalent forms of phosphates (Barea et al. 2011). The simplification of vegetation structure and composition reduces the diversity of hosts and hence has a negative effect on the density, richness and diversity of these soil fungi.

The leaf water content of holm oak trees was dependent on land use, and the same pattern of $\mathrm{P}$ leaf concentration was found. In the Cistus shrub habitat, holm oaks in abandoned areas showed lower leaf water content than trees in pasture. This finding was expected and suggests that differences in root architecture between trees and herbaceous species and similarities between trees and shrubs (Silva and Rego 2003) result in less competition between trees and pasture for water (Moreno et al. 2007). However, Rolo and Moreno (2012) have shown that Cistus spp. roots are nearly all concentrated at surface level, which indicates that Cistus-holm oak competition can be as great as the competition between pasture and holm oak. In addition, the differences in life history between trees and pasture and between trees and shrubs might be another possible explanation, in that plant competition may also be reduced by shortening periods of joint water demand. 
Mediterranean pastures in grazing areas are largely comprised of annual herbaceous species which complete their growth cycle, and hence their soil water demand, at the end of spring when the seeds are produced. Thereafter, during the summer, the little soil water available may be used by holm oak without interference from the pasture. In abandoned areas, the soil water demands of holm oak and C. ladanifer overlap throughout the year, including the dry summer, and thus, competition is sustained for longer and may result in a higher degree of exploitation of water resources. In contrast with our findings in the Cistus shrub habitat, the leaf water content of trees was favoured by the encroachment of mixed shrubs. Therefore, it seems that earlier arguments which focused on the hypothesis of divided resources through rooting-niche separation and life history do not provide a convincing explanation for plant interaction in open woodlands. However, these findings agreed with those of Rolo and Moreno (2011), who found that the shrub Retama sphaerocarpa slightly affected the water status of the holm oak and that there was fierce competition between $C$. ladanifer and the tree, which seriously affected its functional status. In addition, the holm oak can adapt its root depth by itself by achieving a balance between the cost of water and nutrient acquisition and the cost of developing and maintaining a root system; thus, to a degree, the soil use by tree and shrub may sometimes be complementary (Rolo and Moreno 2012). On the other hand, it has been suggested that arbuscular mycorrhizas are able to increase the tolerance of their host to water stress (Augé 2004), which may provide a possible explanation of our results. Several mechanisms have been proposed to explain this effect, including increased root hydraulic conductivity, improved stomatal regulation and improved contact with soil particles through the binding effect of hyphae, which enable water to be extracted from smaller pores. Consequently, the water status of holm oaks is linked not only to the understory type - pasture or shrub - but also to its composition, especially in case of the shrub understory.

Grazing intensity affects the growth pattern and nutrient status of holm oaks. In areas where pastures have been stabilized by livestock use, we have found an increase in shoot length with grazing intensity. A large growth could result in similar or even less nutrient concentration of leaves, due to dilution effect. However, leaf concentration of $\mathrm{N}$ also increased with grazing intensity. These results support the idea that in Mediterranean open woodland, grazing increases the size of the inorganic $\mathrm{N}$ pool available in the soil (Augustine and Mcnaughton 2006), stimulating primary productivity not only of pasture but also of trees. Herbivory can also favour the presence of annual legumes in Mediterranean pasture (Rochon et al. 2004), which act as nitrogen fixers increasing the quantity of this nutrient in soils and its availability for other species. Given that holm oaks in nutrient-poor environments have a low competitive capacity for soil $\mathrm{N}$ compared to pasture because of their dense, shallow root system (Rolo and
Moreno 2011), our results suggest that this tree may significantly benefit from soil $\mathrm{N}$ in nutrient-enriched environments, as occurs on farms with high grazing intensity. On the other hand, the foliar concentration of $\mathrm{Mg}$ increases with grazing intensity, even though no differences were found in the soil. $\mathrm{Mg}$ absorption tends to increase in those environments and seasons in which plants experience water stress (Sardans et al. 2008). Accordingly, mean values of leaf $\mathrm{Mg}$ concentration were higher in the second sampling, due to the fact that the sampling was conducted later in the year (in early and late summer, respectively). Given that most minerals are passively accumulated in tissues by the transpiration stream, higher leaf $\mathrm{Mg}$ concentration also implies higher transpiration rates and metabolic activity for trees in plots with heavy grazing (Zhu et al. 2010). However, grazing modifies water flow through the soil, and hence the nutrient uptake. Livestock trampling may reduce the water infiltration rate due to an increase in soil bulk density (Drewry et al. 2008). As a result, less water may accumulate at deeper layers, increasing drought stress in plots with heavy grazing and hence stimulating the absorption of $\mathrm{Mg}$.

In conclusion, land use affects Holm oak performance in Mediterranean open woodland through changes in the structure and composition of the vegetation and changes in soil fertility. The abandonment of grazing encourages shrub encroachment but its effect is different according to the habitat type. In cases where C. ladanifer is the main species involved in this encroachment process, the resulting habitat becomes more stressful for the tree, reducing its opportunities in terms of $\mathrm{N}$ and water acquisition. When mixed shrub species are involved in the encroachment process following abandonment, the resulting habitat may be enhanced, with increased $P$ nutrition and water status of the tree. Although there are social and environmental reasons for maintaining pastoral systems in marginal areas, according to our results, extensive grazing could be a useful management tool to enhance nutritional tree status in poor-nutrient habitats where Cistus species may be dominant, thus contributing to the maintenance of Mediterranean open woodland in the face of climate change. In those open woodlands with a well-developed pasture strata and a scarce shrub understory with a long history of livestock use, the increase of grazing intensity has resulted in an increase of tree growth and leaf $\mathrm{N}$ concentration. A higher growth rate implies higher water consumption, thus extending the season of water stress for these trees. Further research is needed to clarify the effect of grazing and grazing management on soil $\mathrm{N}$ dynamics in Mediterranean open woodlands, linking this with holm oak productivity and its resilience to drought.

Funding This study was sponsored by the Department of Innovation, Science and Business of the Regional Government of Andalusia, Spain (project P10-AGR6501), and the Spanish Ministry of Science (project AGL2009-00530). 


\section{References}

Augé RM (2004) Arbuscular mycorrhizae and soil/plant water relations. Can J Soil Sci 84:373-381. doi:10.4141/S04-002

Augustine DJ, McNaughton SJ (2006) Interactive effects of ungulate herbivores, soil fertility, and variable rainfall on ecosystem processes in a semi-arid savanna. Ecosystems 9:1242-1256. doi:10.1007/ s10021-005-0020-y

Barea JM, Palenzuela J, Cornejo P, Sánchez-Castro I, Navarro-Fernández C, López-García A, Estrada B, Azcón R, Ferrol N, Azcón-Aguilar C (2011) Ecological and functional roles of mycorrhizas in semi-arid ecosystems of Southeast Spain. J Arid Environ 75:1292-1301. doi: 10.1016/j.jaridenv.2011.06

Benlloch-González M, Arquero O, Fournier JM, Barranco D, Benlloch M (2008) $\mathrm{K}+$ starvation inhibits water-stress-induced stomatal closure. J Plant Physiol 165:623-630. doi:10.1016/j.jplph.2007.05.010

Chaves N, Escudero JC (1997) Allelopathic effect of Cistus ladanifer on seed germination. Funct Ecol 11:432-440. doi:10.1046/j.13652435.1997.00107.x

Cubera E, Moreno G (2007) Effect of land-use on soil water dynamic in dehesas of Central-Western Spain. Catena 71:298-308. doi:10. 1016/j.catena.2007.01.005

Dias T, Malveiro S, Martins-Loução MA, Sheppard LJ, Cruz C (2010) Linking N-driven biodiversity changes with soil $\mathrm{N}$ availability in a Mediterranean ecosystem. Plant Soil 341:125-136. doi:10.1007/ s11104-010-0628-3

Drewry JJ, Cameron KC, Buchan GD (2008) Pasture yield and soil physical property responses to soil compaction from treading and grazing - a review. Aust J Soil Res 46:237-256. doi:10.1071/SR07125

Erickson A, Ramsewak RS, Smucker AJ, Nair MGJ (2000) Nitrification inhibitors from the roots of Leucaena leucocephala. J Agric Food Chem 48:6174-6177. doi:10.1021/j9991382z

Gaspar P, Mesias FJ, Escribano M, de Ledesma AR, Pulido F (2007) Economic and management characterization of dehesa farms: implications for their sustainability. Agroforest Syst 71:151-162. doi: 10.1007/s10457-007-9081-6

Gómez-Rey MX, Madeira M, Gonzalez-Prieto SJ, Coutinho J (2013) Soil $\mathrm{C}$ and $\mathrm{N}$ dynamics in a Mediterranean oak woodland with shrub encroachment. Plant Soil. doi:10.1007/s11104-013-1695-Z

Greenwood KL, McKenzie BM (2001) Grazing effects on soil physical properties and the consequences for pastures: a review. Aust J Exp Agric 41:1231-1250. doi:10.1071/EA00102

IUSS Working Group WRB (2006) World reference base for soil resources 2006. 2nd edn. World Soil Resources Reports 103. FAO, Rome

McPherson G (1997) Ecology and management of North American savannas. University of Arizona Press, Tucson

Milla R, Castro-Díez P, Maestro-Martínez M, Montserrat-Martí G (2005) Relationships between phenology and the remobilization of nitrogen, phosphorus and potassium in branches of eight Mediterranean evergreens. New Phytol 168:167-178. doi:10.1111/j.1469-8137. 2005.01477.x

Moreno G, Obrador JJ (2007) Effects of trees and understorey management on soil fertility and nutritional status of holm oaks in Spanish dehesas. Nutr Cycl Agroecosyst 78:253-264. doi:10.1007/s10705007-9089-3

Moreno G, Pulido F (2009) The functioning, management, and persistence of dehesas. In: Rigueiro-Rodríguez A, Mcadam J, MosqueraLosada MR (eds) Agroforestry in Europe: current status and future prospects. Springer, Berlin, pp 127-160. doi:10.1007/978-1-40208272-6 7

Moreno G, Obrador JJ, García E, Cubera E, Montero MJ, Pulido F, Dupraz C (2007) Driving competitive and facilitative interactions in oak dehesas through management practices. Agrofor Syst 70:2540. doi:10.1007/s10457-007-9036-y
Peco B, Sánchez AM, Azcárate FM (2006) Abandonment in grazing systems: consequences for vegetation and soil. Agricult Ecosys Environ 113:284-294. doi:10.1016/j.agee.2005.09.017

Pulido F, García E, Obrador JJ, Moreno G (2010) Multiple pathways for tree regeneration in anthropogenic savannas: incorporating biotic and abiotic drivers into management schemes. J Appl Ecol 47:12721281. doi:10.1111/j.1365-2664.2010.01865.x

Ramírez JA, Díaz M (2008) The role of temporal shrub encroachment for the maintenance of Spanish holm oak Quercus ilex dehesas. Forest Ecol Manag 255:1976-1983. doi:10.1016/j. foreco.2007.12.019

Ritchie ME, Tilman D, Knops JMH (1998) Herbivore effects on plant and nitrogen dynamics in oak savanna. Ecology 79:165-177. doi:10. 2307/176872

Rochon JJ, Doyle CJ, Greef JM, Hopkins A, Molle G, Sitzia M, Scholefield D, Smith CJ (2004) Grazing legumes in Europe: a review of their status, management, benefits, research needs and future prospects. Grass Forage Sci 59:197-214. doi:10.1111/j.13652494.2004.00423.x

Rolo V, Moreno G (2011) Shrub species affect distinctively the functioning of scattered Quercus ilex trees in Mediterranean open woodlands. Forest Ecol Manag 261:1750-1759. doi:10.1016/j.foreco. 2011.01.028

Rolo V, Moreno G (2012) Interspecific competition induces asymmetrical rooting profile adjustments in shrub-encroached open oak woodlands. Trees 26:997-1006. doi:10.1007/s00468-0120677-8

Rolo V, López-Díaz ML, Moreno G (2012) Shrubs affect soil nutrients availability with contrasting consequences for pasture understory and tree overstory production and nutrient status in Mediterranean grazed open woodlands. Nutr Cycl Agroecosyst 93:89-102. doi:10. 1007/s10705-012-9502-4

Sardans J, Peñuelas J, Ogaya R (2008) Drought's impact on Ca, Fe, Mg, $\mathrm{Mo}$ and $\mathrm{S}$ concentration and accumulation patterns in the plants and soil of a Mediterranean evergreen Quercus ilex forest. Biogeochemistry 87:49-69. doi:10.1007/s10533-007-9167-2

Schimel JP, VanCleve K, Cates RG, Clausen TP, Reichardt PB (1996) Effects of balsam poplar (Populus balsamifera) tannins and low molecular weight phenolics on microbial activity in taiga floodplain soil: implications for changes in $\mathrm{N}$ cycling during succession. Can $\mathrm{J}$ Bot 74:84-90. doi:10.1139/b96-012

Seddaiu G, Porcua G, Ledda L, Roggero PP, Agnelli A, Cortic G (2013) Soil organic matter content and composition as influenced by soil management in a semi-arid Mediterranean agro-silvo-pastoral system. Agr Ecosyst Environ 167:1-11. doi:10.1016/j.agee. 2013.01.002

Silva JS, Rego FC (2003) Root distribution of a Mediterranean shrubland in Portugal. Plant Soil 255:529-540. doi:10.1023/ A:1026029031005

Strandberg B, Kristiansen SM, Tybirk K (2005) Dynamic oak-scrub to forest succession: effects of management on understorey vegetation, humus forms and soils. Forest Ecol Manag 211:318-328. doi:10. 1016/j.foreco.2005.02.051

Tárrega R, Calvo L, Taboada A, García-Tejero S, Marcos E (2009) Abandonment and management in Spanish dehesa systems: effects on soil features and plant species richness and composition. Forest Ecol Manag 257:731-738. doi:10. 1016/j.foreco.2008.10.004

Yang HQ, Jie JL (2005) Uptake and transport of calcium in plants. J Plant Physiol Mol Biol 31:227-234

Zhu L, Li SH, Liang ZS, Xu X, Li Y (2010) Relationship between carbon isotope discrimination, mineral content and gas exchange parameters in vegetative organs of wheat grown under three different water regimes. J Agron Crop Sci 196:175-184. doi:10.1111/j.1439-037X. 2009.00404.x 